\title{
Making the UN Ocean Decade work? The potential for, and challenges of, transdisciplinary research \& real-world laboratories for building towards ocean solutions
}

Andrea Franke ${ }^{1,2, *}$, Kimberley Peters ${ }^{1,2,3}$, Jochen Hinkel ${ }^{4,5}$, Anna-Katharina Hornidge ${ }^{6,7}$, Achim Schlüter ${ }^{8,9}$, Oliver Zielinski ${ }^{10,11}$, Karen H. Wiltshire ${ }^{12}$, Ute Jacob ${ }^{1,2}$, Gesche Krause $^{2}$, Helmut Hillebrand ${ }^{1,2,3}$

${ }^{1}$ Helmholtz Institute for Functional Marine Biodiversity at the University of Oldenburg (HIFMB), Ammerländer Heerstr. 231, 26129 Oldenburg, Germany

${ }^{2}$ Alfred-Wegener-Institute, Helmholtz-Centre for Polar and Marine Research (AWI), Am Handelshafen 12, 27570 Bremerhaven, Germany

${ }^{3}$ Institute for Chemistry and Biology of the Marine Environment (ICBM), Plankton Ecology Lab, Carlvon-Ossietzky University Oldenburg, Schleusenstr. 1, 26382 Wilhelmshaven, Germany

${ }^{4}$ Global Climate Forum, Neue Promenade 6, 10178 Berlin, Germany

${ }^{5}$ Albrecht Daniel Thaer-Institute, Humboldt-Universität zu Berlin, Invalidenstr. 42, 10099 Berlin, Germany

${ }^{6}$ German Development Institute / Deutsches Institut für Entwicklungspolitik (DIE), Tulpenfeld 6, 53113 Bonn, Germany

${ }^{7}$ University of Bonn, Department for Political Sciences and Sociology, Lennéstr. 25-27, 53113 Bonn, Germany

${ }^{8}$ Leibniz Centre for Tropical Marine Research, Social Science Department, Fahrenheitstr. 6, 28359 Bremen, Germany

${ }^{9}$ Jacobs University Bremen, Department of Business and Economics, Campus Ring 1, 28759 Bremen, Germany

${ }^{10}$ Institute for Chemistry and Biology of the Marine Environment (ICBM), Center for Marine Sensors, Carl-von-Ossietzky University Oldenburg, Schleusenstr. 1, 26382 Wilhelmshaven, Germany

${ }^{11}$ German Research Center for Artificial Intelligence (DFKI), Marine Perception Department, MarieCurie-Str. 1, 26129 Oldenburg, Germany

${ }^{12}$ Alfred-Wegener-Institute, Helmholtz-Centre for Polar and Marine Research (AWI), Wadden Sea Station, Hafenstr. 43, 25992 List/Sylt, Germany

*Corresponding author: Andrea Franke, Helmholtz Institute for Functional Marine Biodiversity at the University of Oldenburg (HIFMB), Ammerländer Heerstr. 231, 26129 Oldenburg, Germany, Email: andrea.franke@hifmb.de

\section{Keywords}

Ocean sustainability, ocean governance, ocean literacy, societal challenges, real-world experimentation, living labs, SDG 14, marine conservation, marine ecosystem functioning 


\begin{abstract}
This paper provides a critical contribution to the UN Decade of Ocean Science for Sustainable Development 2021-2030, outlining some of the core challenges of sustainable ocean governance and management by reflecting on modes and logics of interactions between ocean-related sciences, policymakers and practitioners. In this regard, we give an overview of the potential for, and challenges of, transdisciplinary research which is essential to understanding the linkages between oceans and societies and thereby for attending to contemporary ocean concerns. The paper contributes both a review of transdisciplinary research and a particular format of transdisciplinary experimentation: Realworld Laboratories (RwLs). These are currently gaining traction as a method and approach for the cocreation of knowledge between the natural and social sciences and society to foster sustainability transformations. Altogether, we offer a first major contribution to synthesising knowledge on the potentials of marine RwLs, considering how they act as a way of exploring options for sustainable ocean futures through experimentation. Indeed, in the marine context, RwLs are under-explored but are a vital way for addressing the societal challenges of working towards transformations over the coming UN Ocean Decade.
\end{abstract}

\title{
1. The ocean crisis
}

The oceans, seas and coasts and the multiple uses of their (non-)living resources have always been central to societies worldwide. The marine environment provides food and energy, facilitates trading and transport of goods, generates jobs and is pivotal in securing human health and well-being (Fleming et al., 2019; Visbeck et al., 2014). According to the FAO, fisheries and aquaculture form the basis of livelihood provision for more than 10 percent of the world's population (FAO, 2018) and in many countries, fish and seafood are an essential source of protein (FAO, 2020).

The ocean has long been perceived as an endless resource reservoir and anthropogenic pressures on the ocean system were assumed to be negligible (Steinberg, 2001). However, it has been adversely affected through human pressures such as climate change, overfishing, pollution, habitat destruction and underwater mining for a long time (Duarte, 2014; Hoegh-Guldberg \& Bruno, 2010). In this context, sustainable ocean and coastal management, which pursues ecosystem-based, integrative and multifunctional approaches and promotes a paradigm shift towards 'building with nature', is increasingly demanded (Temmerman et al., 2013; van Slobbe et al., 2013).

Moreover, the Blue Economy, in spite of its aim to build blue sustainable growth around sectors such as fisheries, aquaculture, tourism, deep-sea mining and shipping, is largely set up in an unsustainable manner (Bennett et al., 2019; Ertör \& Hadjimichael, 2020). The cumulative pressures of both global change and ocean exploitation endanger the health of the ocean and its ecosystems (Jouffray et al., 2020). Consequently, there is an unprecedented loss of marine biodiversity, affecting ecosystem functioning (IPBES, 2019; IPCC, 2019) but also public health and well-being linked to the ocean (Borja et al., 2020).

In spite of being essential to the functioning of physical, biological and societal processes, the ocean is the least understood ecosystem on earth (Antich et al., 2021; Reusch et al., 2021) and has remained 'out of sight and mind' (Peters, 2010) resulting in a lack of ocean literacy (Kelly et al., 2021). However, awareness of the unsustainable use of marine ecosystems has been raised in recent years and led to the United Nations Decade of Ocean Science for Sustainable Development 2021-2030 (UN Ocean Decade) and the explicit ocean-related Sustainable Development Goal 14 'Life below Water' (SDG 14) of the UN 2030 Agenda for Sustainable Development. SDG 14 formulates ambitious targets to ensure 
the conservation of marine biodiversity, for example "by 2020, sustainably manage and protect marine and coastal ecosystems to avoid significant adverse impacts [...] and take action for their restoration in order to achieve healthy and productive oceans". Nevertheless, the question of how to achieve these targets remains largely open and is to be defined on national, regional and global levels. Moreover, local, traditional and indigenous knowledge are needed and should not be ignored in such developments (Belhabib, 2021; Blythe et al., 2021; Tilot et al., 2021). The latter presents a challenge for ocean governance, whose foundational structures are grounded in western territorial management regimes (Peters, 2020). Conflicting societal interests, lack of political will, ineffective science-policy interfaces, geopolitics, 'power plays', weak ocean governance and a lack of operational frameworks and management plans are just some of the limitations (Germond, 2018). For example, large-scale marine protected areas (LSMPAs) are set up to meet international protection targets but poorly monitored and enforced (resulting, in effect, in nothing more than 'paper parks'; Alger, 2021).

The UN Ocean Decade, arguably offers an opportunity to mobilise action for increased ocean literacy and a transformation towards more sustainable forms of interaction. It aims to be inclusive and representative in its approaches to ocean science and the building of applicable knowledge, solutions and innovations. But this is not without its challenges. Whilst capacity development is central to the work of the UN Ocean Decade, there is also a need to acknowledge power systems that enable certain knowledge to dominate in potential ocean futures. As Tolochko \& Vadrot (2021) argue, it is still the 'usual suspects' or dominant 'players' producing marine biodiversity knowledge and sustainable solutions. Hence, there is a need to be cognisant of the 'dark sides' (risks) of transformation, as for example "shifting the burden of response onto vulnerable parties" (for further details see Blythe et al., 2018).

This interdisciplinary paper offers a critical contribution to the UN Ocean Decade, outlining some of the core challenges of marine sustainability and ocean governance by reflecting on modes and logics of interaction between ocean-related sciences, policy-makers and practitioners (see section 2). Moreover, it provides an overview of the potentials for and challenges of transdisciplinary research, essential to understanding the linkages between oceans and societies, and focuses on a particular transdisciplinary approach: real-world laboratories (RwLs). RwLs facilitate the co-creation of research and knowledge between science and society to foster 'just' sustainability transformations (Schäpke et al., 2018; Wanner et al., 2018) but have thus far been under-explored in the marine context (see section 3). Therefore, they are considered here as a method for 'real-world' problem solving in the marine realm and the development of transformative pathways towards sustainable ocean futures (see section 4 and 5).

\section{The societal challenges of progressing towards ocean sustainability}

Since the ocean and our societies are heavily interconnected, it is crucial to achieve and maintain ocean health and sustainability to safeguard food security, people's livelihoods, health and well-being (Franke et al., 2020). However, marine sciences have traditionally not comprised social sciences, making it difficult to unravel the interactions between marine ecosystems and social systems (Bennett et al., 2019). Consequently, the conservation and restoration of the ocean are significant challenges since many perspectives - societal, political, economic and relations between these - have to be taken into consideration. Apart from the general lack of ocean literacy, existing knowledge seems to be unevenly distributed around the globe (Tolochko \& Vadrot, 2021). For example, many marine ecosystems of worldwide importance are situated in the tropics. However, literature research clearly shows that system knowledge production is not led by scientists coming from these regions, which 
might bring a less fitting perspective and cement unilateral dependencies (Partelow et al., 2020). Though a body of work led by Majority World (Global South) scholars in the humanities (literature, art, post-, de- and anti-colonial thought) gives voice to perspectives beyond the west is important to note (Goodyear-Ka'opua, 2018; Hau'ofa, 1995; Hofmeyr, 2020; Underhill-Sem, 2020; Zondi, 2020), marine social sciences have, to date, scantily engaged in this rich work.

Another main problem in addressing the ocean crisis is that the ocean is a global commons, leading to a range of nested collective dilemmas on various social, economic and geographical scales (Abhold et al., 2019; Glaser \& Glaeser, 2014). In marine spaces different jurisdictions and social systems meet and, due to the fluidity and multi-dimensionality, are de facto overlapping (Schlüter et al., 2019, 2020; P. Steinberg \& Peters, 2015; van Assche et al., 2020). Many marine governance and management tools are built, literally, from land-based norms where there is greater experience (Peters, 2020). These techniques are arguably less suited to the dynamism of the seas and oceans since governing a mobile resource is much more complex than a stationary resource (Peters, 2020). The emerging socio-political dilemmas can only be solved by intensive, equitable, interaction between the various jurisdictions, as seen in HELCOM, OSPAR, UNCLOS, or other governance bodies, which need to be understood and improved constantly, to meet the new arising challenges. It is thus fundamental to support negotiations on ocean matters within multilateral institutions with empirically 'sound' research to provide a basis for working towards connected-up governance for what are connected-up, transboundary problems.

Moreover, the strategic relevance of the ocean and its resources as the subject of global geopolitical power relations and negotiating processes (e.g. at the International Seabed Authority) continues to be underestimated. Social inequality and marked global and sectoral differences in negotiations of power are contributing to situations that adversely affect the incomes and nutritional situation of some countries, particularly in the Global South (e.g. EU fisheries partnership agreements). Another example are the recent BBNJ (Marine Biodiversity of Areas Beyond National Jurisdiction) negotiations. In spite of being pitched as a global treaty, many countries - some with large stretches of coast - remain underrepresented or beholden to western pots of money to participate (De Santo, 2018; Mendenhall et al., 2019). There is clearly a need for greater openness in participation but also to listen to opinions, knowledge, ideas, visions and potential solutions for ocean futures that may not always align neatly, and may also contradict dominant desires, on how to 'save' the ocean.

Certainly, participatory approaches for building sustainable ocean futures must enable the involvement of everyone with stakes in the future of oceans and marine resources. In order to build knowledge partnerships for sustainable ocean governance steps must be taken to boost the negotiating clout of coastal states in regional and multilateral Blue Economy debates on ecosystem conservation and job creation. To this end, it is suggested that it is necessary to develop regional networks between policy-makers and researchers based on local (scientific and non-scientific) knowledge systems in the fields of marine conservation, ocean governance, sustainability, climate change and development research. It is a fundamental prerequisite to imagine futures where local, traditional and indigenous knowledge are front and centre instead of including local knowledge within existing frameworks (frameworks that are themselves burdened with western power logics) (Brown \& Peters, 2018; Hau'ofa, 2008; Yusoff, 2018).

Thinking about sustainability transformations also requires a discussion about the targets and thus normative research enabling transformational shifts. Even though there is a global consensus on the need of ocean sustainability (see SDG 14), an intensive societal discussion process is required to ascertain what sustainability - in a particular geographical, sectoral or holistic context and in a certain 
moment in time - means and whose sustainability perspective counts (Bromley, 1998). Whilst certain marine system knowledge is now acquired and interdisciplinary scientific cooperation established and we are aware of governance challenges - neither jointly negotiated target knowledge (where to go), nor transformation knowledge (how to reach the new stage) exists to a sufficient degree (Pohl \& Hirsch Hadorn, 2007). Moreover, transregional learning from each other's 'solutions' - while each time embedding them into local context to assure 'local fit' and applicability - needs to be further understood and structurally fostered (Hornidge et al., 2020).

In summary, our societal responsibility of working towards sustainable development and a healthy ocean requires a 'just' transformation. Such a process will be a challenging endeavour due to the complex nature of the ocean (a space of commons, social dilemmas and fluidity), the manifold pressures it is facing, the lack and asymmetry in distribution of knowledge, low societal ocean literacy and insufficient ocean governance arrangements. Hence, holistic and inclusive approaches, such as transdisciplinary research and experimentation (e.g. in the form of RwLs), involving all necessary stakeholders are crucially needed.

\section{Working towards ocean sustainability: Potentials and challenges of transdisciplinarity}

\section{Transdisciplinary research}

In general, transdisciplinary research denotes a multitude of research approaches that abandon the traditional division of labour between science as knowledge producer and society as knowledge applicant. Instead, in transdisciplinary models of knowledge production, research questions, processes and products are developed collaboratively among researchers and broadly-defined stakeholders making use of local knowledge systems and cultures.

This idea has been present for decades under various labels, including action research (Lewin, 1946), post-normal science (Funtowicz \& Ravetz, 1993), mode-2 knowledge production (Gibbons et al., 1994), participatory research (Cornwall \& Jewkes, 1995), co-production (Watson, 2014) and transformative research (Anderson \& McLachlan, 2016). At the same time, the implementation of transdisciplinary approaches and 'real-world' embedding in the actual field of research is challenged by existing incentive mechanisms within the science systems (e.g. focus on scientific high-impact publications instead of community engagement) as well as the socio-political environments in which and for which the research takes place - in marine just as in terrestrial ecosystems (Hornidge et al., 2011).

The core aspiration of transdisciplinary research is to contribute to 'real-world' problem solving through experimentation instead of advancing research in its own right (Cash et al., 2003; Hinkel et al., 2016; Moss et al., 2013). In order to do so, transdisciplinary research is situated in a particular social context, place and issue (Norström et al., 2020) and follows a range of normative principles conducive to solving social conflicts. These principles include recognizing multiple ways of knowing and doing, fostering deliberation, mutual learning and trust building among actors through the creation of safe spaces in which they can express their own opinions, interests and experiences (Brandt et al., 2013; Mielke et al., 2017; Norström et al., 2020). A wide range of participatory methods, many of which originate from the related fields of public or citizen participation (Callahan, 2007), have been applied to implement these principles. Nowadays, public participation is widespread and particularly popular in environmental governance (Birnbaum, 2016). The European Commission, for example, has issued a Public Participation Directive (Quittkat \& Kohler-Koch, 2013). Other Directives, such as the EU Water 
Framework Directive, foresee the involvement of a wide range of stakeholders in all steps of the planning and implementation (Challies et al., 2017).

\section{Transdisciplinary experimentation}

A core element of many transdisciplinary research approaches is experimentation followed by reflection, as first articulated through the concepts of action research (Lewin, 1946) and reflective practitioners (Schön, 1983). The idea is that the 'right' response to complex societal issues cannot be known beforehand, as abilities to predict complex systems are limited. Hence, there is a need to first experiment, in order to then be able to observe, reflect and learn for next steps. Experimentation at the interface of science and society can thereby target the biophysical realm, for example, experimenting with different ecosystem management approaches (Armitage et al., 2009), as well as the social realm, for example, experimenting with different governance arrangements (Folke et al., 2005).

With regard to the social realm, it is important to critically contextualise experimentation since it may not always be positive or transformative. Literature in the social sciences and humanities has cautiously and reflectively considered the laboratory work of natural science as a site of experimentation and testing (Kullman, 2013; Last, 2012). Whilst experimentation has potential for 'good' in building and integrating knowledge for solutions, experiments may also be based upon particular contextual constructions of people and places that position societies and geographies as 'in need of testing' or 'ripe for testing'. Experimentation therefore has ethical dimensions and always holds dimensions of power. Consider, for example, nuclear testing in the Pacific Ocean in the 1950s. The Atolls were used as a live lab of violent experimentation on people and environments (Yusoff, 2018). Although, at the time, those doing the experiments believed there could be some 'good' in those tests for understanding the impacts of nuclear weaponry and technology - they employed those labs on the construction of certain Pacific Ocean areas as 'empty' (and thus 'free' for experimentation) and Pacific Islanders as less than human (and thus disposable) (Yusoff, 2018). Whilst this may seem a long way from transdisciplinary experimentation, notions of who experiments, why, for and on behalf of whom, for what knowledge and who benefits/loses, with reflections on positions of power, are vital. Thus, when proposing RwLs as a form of real-world experimentation here, we propose participatory ones - where the testing and experimenting is conducted hand-in-hand with those it could impact. Top-down experimental western science otherwise has the potential to be exploitative and damaging and to impose outcomes on people it aims to assist.

\section{Real-world laboratories}

In recent years a multitude of real-world experimentation approaches, such as real-world laboratories (RwLs), living labs (LLs), transition labs, transformation labs and innovations labs have emerged (Hossain et al., 2019; Huning et al., 2021). Standard definitions for the different approaches do not exist, which means that terms like RwL and LL seem to be used interchangeably. However, the different definitions and variants all have a common core: they are solution-oriented, experimental and 'laboratory' research settings, attempting to accelerate transformations together with and for the society towards more sustainability (Schäpke et al., 2018). Here we focus on RwLs which can be described as a targeted set-up of a research 'infrastructure' or a 'space' in which scientists and actors from the civil society jointly invent and conduct real-world experiments to produce system, target and transformation knowledge for a more sustainable development of society (Schneidewind et al., 2018; WBGU, 2016). The different stakeholders involved are ranging from scientists to the general public, (non-)governmental organisations and businesses. 
According to Schäpke et al., 2018, the core characteristics of RwLs are (i) the contribution to sustainability transformation using a transdisciplinary research mode and experimental methods, (ii) the scalability and transferability of the results and (iii) scientific learning, societal learning and reflexivity. Overall, RwLs focus on producing evidence for potential solutions to societal challenges with the overarching goal to foster transformation.

The science-practice interaction of a RwL consists of three phases in which all stakeholders are involved from the beginning onwards: (i) a co-design phase, where problems and potential solutions are discussed and selected (ii) a co-production phase, where experiments are conducted and selected innovations are implemented and tested; and (iii) a co-evaluation and adjustment phase, which consolidates the innovations (Wanner et al., 2018).

\section{Lessons learned}

Transdisciplinary research aiming at the co-creation of transformative knowledge for implementation has gained prominence over the past twenty to thirty years, but largely in terrestrial settings. Particularly wide-scale experiences have been collected in agricultural research, development and environmental research and urban planning. However, transdisciplinary research, especially when using experimental approaches such as RwLs, is generally a challenging endeavour. One reason is that many educational systems are mainly based on disciplinary training which fosters a disciplinary mindset within scientific communities instead of inter- or transdisciplinary ways of thinking and interacting (Knapp et al., 2017). Over recent years, inter- and transdisciplinary master programmes are increasingly being offered, however, this is a rather new trend and one has to keep in mind that most scholars involved in current research have most likely a rather fixed disciplinary background. In other words, they bring a set of traditions (or disciplinary 'baggage') with them. Hence, transdisciplinary projects, in crosscutting disciplines and sectors, have different timescales, goals and measures of success compared to disciplinary projects and therefore require long-term funding. Changes in both natural and social systems take place on scales of years to decades. This results in a direct need for long-term planning, support and financing (particularly of RwLs) to secure the need for specialised technologies, observing systems and experimental equipment. Typically, funding instruments of public authorities and other organizations are designed for periods of 2 to 6 years. Hence, long-term research perspectives and infrastructures are usually funded through a series of projects with changing priorities that build on each other. The dangers of this approach lie in the unreliability of gaining consecutive funding and in the changing of topics or priorities of funding agencies. Thus, to capture transformative effects, long-term research programs (10 to 30+ years) would be appropriate, allowing for exchange, comparability and transparency on larger time scales. Analogous to Weller et al. (2019), "to grow the pool of users", to sustain long-term operation of a RwL is key.

Another challenge is that stakeholders, as well as the policy, governance and legal frameworks that are to be optimized, must be initially identified and followed-up with continuous communication, (intercultural) dialogs, knowledge exchange and outreach. Established trust within cooperation networks of different stakeholders can be an essential ingredient of a successful RwL. Yet whilst stakeholder engagement, exchange and participation are intended to be inclusive, power plays may persist during decision making on potential interventions. Accordingly, as some scholars show, participatory processes may be captured by powerful interest groups to enforce their interests potentially leading to worse outcomes than non-participatory processes (Flannery et al., 2018; Singleton, 2000). 
To avoid misunderstandings and communication problems, the coherence of the used terminology and definitions is of utmost importance. To ensure that all RwL partners understand each other, the relevant keywords and central definitions for the respective RwL need to be jointly identified, collected and/or defined. For example, terms like 'marine system', 'sustainability', 'life quality' or 'resilience' might have different meanings for different stakeholders which may lead to fundamental problems regarding the formulation of the RwL objectives and goals.

Furthermore, applied methods and technologies (e.g. utilization of existing data sources, repeated field measurements, fully autonomous environmental monitoring systems) are subject to constant change and oftentimes the partners in an RwL are not equipped with the same technologies for taking measurements. This need not be an obstacle for good measurements, as successful intercalibration projects show (Acri et al., 2020; Chander et al., 2013), but it is one of many components that require careful support from start to finish. The handling of data and information is another critical aspect that is highly relevant for the success of RwLs. Precisely because RwLs are characterized by participation and interaction, transparency and open handling of data are key success factors. Eventually, long-term and sustainable coordination among different transdisciplinary projects and RwLs should be achieved, promising a significant increase in individual project success and a more efficient use of resources. An example, for the increasing need to join up smaller projects into larger networks, is the Mediterranean Sea turtle rescue network (Ullmann \& Stachowitsch, 2015). The research points out the problem of having many programs, stakeholders and interests but no overarching management consortia. Developing larger, coordinated networks would ultimately enhance the communication of transformative approaches towards society and foster knowledge exchange from a local to a global scale, which is indispensable for sustainable acceptance and support.

While co-creation processes always vary depending on the focus, type of innovation, stakeholders, political, social, economic, ecological etc. context, several generalizable learnings and requirements for RwLs can be extracted (Hornidge et al., 2011; Norström et al., 2020; Ul Hassan et al., 2011):

1. The process should be clearly situated within a particular context, place or issue.

2. All necessary stakeholders should be involved before the start of the project. Roles and priorities should be clarified in the transdisciplinary team from the start.

3. Substantial attention should be paid to a systematic, continuous, well-documented, transparent and reliable team interaction and communication.

4. Shared and meaningful goals and innovations, related to the challenge at hand, should be codesigned and clearly defined. Innovation packages should not be too complex.

5. Multiple ways of knowing, doing and communicating should be explicitly recognized. Conscious investment into a culture that encourages the mutual exchange of knowledge (to overcome feelings of superiority and inferiority), fosters flat hierarchies, builds trust and true interests in each other's expertise is needed.

6. Joint decision making during the entire process of co-development (incl. finances) is important. If only certain groups have the decision-making power while others are supposed to follow, ownership diminishes with negative effects on the co-production of knowledge.

7. Individual and institutional level capacity development as well as team facilitation are crucial. Attention has to be paid to the facilitation being supportive without creating a dependency trap. 
8. Transdisciplinary innovation development processes are time and resource intensive and require well trained, continuous local staff (incl. local language expertise). If it is not possible to budget for an at least three-year project with respective resources, it is not advisable to invest at all in a co-ownership producing process.

9. The results of co-produced knowledge, the innovations, should be co-evaluated and reassessed on a regular basis in order to judge if they still pose 'plausible promises' for an improved situation or have lost that potential due to adjustments to stakeholder needs.

\section{Overcoming the ocean crisis: From traditional participatory approaches to real-world laboratories}

Above we describe the core characteristics, potentials and challenges of RwLs, as a transdisciplinary approach. These features illuminate that RwLs - if especially designed for the marine realm - have the potential to be a helpful tool to create transformation knowledge crucially needed to foster ocean sustainability and potential solutions together with and for the society. To demonstrate this potential, we next draw on marine examples of traditional participatory approaches in general, and RwLs in particular.

\section{Participatory approaches in marine settings}

There is a long history of participatory approaches in marine community, conservation, restoration and ecological engineering projects involving stakeholders, scientists and users, for the protection, study, management and enhancement of biodiversity (Abelson et al., 2016; Krause et al., 2020). For example, the compatibility of coastal protection with simultaneous strengthening of ecosystem services, e.g. water purification, binding of pollutants and/or strengthening of recreational value, has been shown in various coastal engineering and building with nature studies (Narayan et al., 2016; Temmerman \& Kirwan, 2015). Other examples include (i) the world's largest and most successful eelgrass restoration project on the Atlantic west coast (Virginia, USA) (Orth et al., 2020), (ii) efforts in certain Great Barrier Reef areas where science, citizens and management have been working together to manage reef decimation by the Crown-of-Thorns starfish (GBRMPA, 2021), (iii) long-standing, experimental programmes for the reintroduction of the European Oyster to the German North Sea and the European Lobster into the Borkum Riffgrund offshore wind farm in the North Sea (Pogoda et al., 2020), (iv) the development of a strategy to deal with climate-induced problems of sea level rise along the Wadden Sea of Schleswig-Holstein in Germany (Wadden Sea Strategy 2100, Germany) where a transparent process was initiated, including project partners from both governmental and non-governmental organizations facilitating a high level of communication and intercultural dialog (MELUR, 2015).

However, despite some success in restoring and conserving structural parts of ecosystems (e.g. vegetation and habitat structures) and populations of single species, restoring whole ecosystems to a functioning state has proven to be very challenging due to the high complexity of the human-ocean system. The level of ecological and socio-economic benefits deriving from marine protected areas (MPAs), for example, remain difficult to predict (Edgar et al., 2014). Hence, their effectiveness is under debate (e.g. Pendleton et al., 2018). It is argued that marine conservation targets based on area alone are not sufficient to optimize protection of marine biodiversity (Abelson et al., 2020; Krause et al., 2020) while stakeholder engagement was found to be the most important factor for the success of MPAs (Giakoumi et al., 2018). 


\section{Marine real-world laboratories}

Since biodiversity in marine systems has never before been under such anthropogenic threat, it is crucial that concepts such as RwLs - which are co-designed, co-produced and co-evaluated with stakeholders - are applied in the marine context to connect up transdisciplinary methodologies and community efforts to foster knowledge building, communication, transparency, compliance and/or experimental work.

Even though the use of RwLs in marine and coastal settings is not very common, the number of implementations of the approach is currently increasing. One example is the project 'Gute Küste Niedersachsen' ('Good Coast Lower Saxony', Germany), which was started in 2020 and aims to investigate and promote ecosystem strengthening coastal protection at the Lower Saxony North Sea coast using a RwL approach. The five-year joint project focuses on the following research questions: (i) how robust, multifunctional and especially ecosystem strengthening coastal protection measures work in the long run and (ii) how they are simultaneously considered in reliable planning and approval by the responsible authorities and accepted by civil society. Both questions are to be answered in RwLS to be defined during the project. Scientists, non-scientific stakeholders and other local actors will already be involved in the selection of RwL sites and the co-design of the research itself (following Mauser et al., 2013). Knowledge co-production will be ensured through regular exchange and reflection. The initial co-design process is nearly completed and has shown so far that, in addition to the spatial conditions as well as the ecological, legal and socio-economic dimensions, the existence of already available (research) infrastructures and preliminary scientific work is of high relevance for all parties. In this regard, it is noteworthy that coastal and ocean observatories, long-term time series and digital inventories, such as recording archives, have been in operation for decades and their advanced experience (at least on the technological and operational side) can be used as a basis for the development of marine RwLs (Muelbert et al., 2019; Weller et al., 2019).

In the project 'Wissen Schafft Lebensraum' ('Knowledge Creates Living Space'), the RwL approach was used to build a network of approx. 50 stakeholders to develop the coastal region around the harbour city of Bremerhaven (Germany) into a model region for sustainable food production and supply including aquaponics (Fuchs \& Krause, in prep.). Bremerhaven has a historically important fishing port however continuously declining fisheries require a structural transformation of the area. The recently completed concept phase of the project revolved around the co-definition of goals, the coidentification of stakeholders and consensus building regarding adequate communication formats to be used (e.g. a problem-focussed series of focus groups). To continuously consider different stakeholder interests over the entire project period, a pre-formulation of project goals by the scientific and/or the initial stakeholder groups was avoided as this would degrade the other stakeholders to spectators. It also became clear that not only the objectives of the project are of central importance but how they are going to be implemented. In this regard, the key actors, that have the necessary influence to enable transformative processes towards the development of regional and sustainable food production systems, were identified to jointly develop actionable transformative pathways.

Another example is the pilot project 'Eckernförder Bucht 2030' ('Eckernförder Bight 2030', Germany). The aim of this marine RwL is "to contribute to the protection of biodiversity, the improvement of water quality and thus to the achievement of the objectives of the EU MSFD and the Baltic Sea Action Plan of the intergovernmental Baltic Sea Protection Cooperation HELCOM." The area is characterized by designated nature reserves but also by high agricultural nutrient input into the sea, tourism, fishing and military presence. One of the goals of the RwL is to assess the extent to which coastal protection measures can contribute to improving the ecological situation in the area. 
Examples for real-world experimentation approaches in a coastal context can also be found in the Netherlands, where the term LL instead of RwL appears to be predominant. The LL'Holwerd aan Zee', for example, is a testing ground for the sustainable development of the Wadden Sea coastal area of Fryslân and Groningen (Zijlstra, 2019). Here, different research institutions, citizens, entrepreneurs and (non-)governmental organisations are working on solution-oriented research questions and innovations regarding saline agriculture, flood risk management and building with nature, sustainable energy production but also recreation, tourism and healthy ageing. In another Dutch consortium, over 90 public and private partners joined forces resulting in the 'Delta Plan for Biodiversity Recovery'. Apart from running the coastal LL 'B7' the consortium is set to find comparable LL standards which are representative of all landscapes in the Netherlands and can be translated accordingly into all possible practice situations for the maintenance of biodiversity in rural areas and extended into the marine environment in future.

\section{Implications and future perspectives}

The vision of the UN Ocean Decade is to "(...) coordinate interdisciplinary research efforts at all levels, in order to generate and use knowledge for the transformational action needed to achieve a healthy, safe, and resilient ocean for sustainable development by 2030 and beyond" (UNESCO, 2020). Transformation towards ocean sustainability is necessarily a journey towards the unknown and therefore requires real-world experimentation. Marine RwLs represent an opportunity to jointly perform this kind of transdisciplinary experimentation, at the interface of science and society, supporting capacity development at all levels (individual, organizational and enabling environment) and allowing for immediate reflexivity. In particular, marine RwLs have the potential to advance (i) ocean management and governance, (ii) ocean literacy and (iii) the blue economy and therefore help to address the key challenges of the UN Ocean Decade. In this conclusion we bring together our discussions thus far and set out the opportunities for marine RwLs as a transdisciplinary tool, under the headings (i-iii) before briefly discussing their limitations.

\section{(i) Ocean management and governance}

To date, most marine management goals are static as they aim to achieve a certain status (e.g. the MSFD GES). However, the ocean and its ecosystems are changing constantly due to their spatial fluidity and spatial-temporal variability (e.g. rapid turnover of biodiversity, adaptation etc.) which requires goals that take the dynamics of the marine realm into account. Due to the cyclical design of RwLS including a co-evaluation phase, RwLs present a feasible opportunity to co-develop dynamic management goals and frameworks while at the same time investigating their operationality and societal acceptance therefore putting research into practice.

Potentially one of the most interesting concepts for marine biodiversity management in RwLs is the concept of biodiversity enhancement, encompassing enhancement of species, food webs and habitats. This can involve the development and implementation of active intervention strategies to counteract anthropogenic pressures on marine ecosystems and hence slow down or prevent their further degeneration. These strategies, such as the reduction of ocean plastic debris or mangrove reforestation, are often characterized by a lack of scientific knowledge transfer (Cormier-Salem \& Panfili, 2016; Dharmawan et al., 2017; Rochman, 2016). Other proposed intervention strategies, such as improving coral reef resilience through assisted evolution, are not being implemented partly due to moral and ethical concerns (Anthony et al., 2017; van Oppen et al., 2015). Given that active interventions are (potentially) controversial, starting a societal dialogue on their feasibility, risks and benefits is crucial. For carrying this out, RwLs provide a suitable platform and therefore can help to 
work towards societal consensus by providing a democratic communication backdrop between interested parties leading to the co-development of novel governance strategies. Marine RwLs on assisted evolution, for example, would be an excellent opportunity to learn from terrestrial restoration strategies where the planting of tree seedlings genetically adapted to climate change is already a standard method (Erickson, 2012).

Altogether, RwLs hold potential to grapple with the qualities, forms and temporalities of the ocean that typically make governance approaches slippery. This is because a RwL creates space for participatory knowledge that allows in-depth and prolonged engagement with certain areas and stakeholders. Ultimately, 'better' governance and management can arise through increased understanding of the linkages between society and areas of the sea.

\section{(ii) Ocean literacy}

To generate the willingness to save and protect our ocean, people must first develop an understanding about its ecological and economic values (Kollmuss \& Agyeman, 2002). However, many marine ecosystem services have very complex, long term and/or often not directly measurable and monetizable effects on human wealth, health and well-being. Therefore, it is not surprising that citizens often have a limited understanding regarding the human-ocean relationship (i.e. both the effects we have on the ocean but also the effects the ocean has on us). Especially, since there is a lack of marine topics in school curricula and still a low level of outreach to, and involvement of, citizens in marine research promoting ocean literacy (Fauville et al., 2019). To discuss and evaluate the (normative) values of marine ecosystem services in a societal dialogue, qualitative and extensive formats of participation facilitating knowledge exchange, like marine RwLs, can be particularly useful (Zivkovic, 2018). A recent systematic review on the effectiveness of ocean literacy points out that there is little correlation between knowledge and behaviour change hence providing knowledge is just one part of the solution (Stoll-Kleemann, 2019). Instead moral engagement through the promotion of new social norms and identities may elicit behaviour change (e.g. in regard to travel patterns, energy, material and food consumption) and encourage ocean citizenship leading to improved ocean health (McKinley \& Fletcher, 2012; Stoll-Kleemann, 2019). Marine RwLs have the potential to play a crucial role in these collective processes due to their participatory nature warranting that all actors are involved from the beginning to the end of transformative projects therefore becoming part of the solution.

\section{(iii) Blue economy}

Transformative change argues for a paradigm shift: from 'blue growth' to a 'sustainable blue economy'. For this shift to happen, economic activities in coastal and marine areas need to reduce their cumulative impacts on the marine environment and value chains need to transform themselves to contribute to a circular economy, net-zero carbon emission, zero pollution, coastal resilience and responsible food systems. To achieve such ambitious goals, transdisciplinary research ensuring crosssector stakeholder involvement is essential. The analyses of historical fisheries or aquaculture casestudies, for example, highlight the diversity of values and needs that different stakeholder groups may have, however, current blue growth agendas do not explicitly consider this diversity (Caswell et al., 2020). The authors concluded "that when the desires of only a subset of stakeholders are considered, short-term ambitions may be prioritized over long-term sustainability, and the perspectives and needs of the weakest stakeholders may be overlooked" (Caswell et al., 2020). To overcome these barriers, the RwL approach could be particularly helpful. Furthermore, RwLs provide the perfect basis for prototype testing, validating new marine technologies and services in real-life environments as they 
involve Public-Private-People Partnerships in the co-creation process (Engel et al., 2020). They are also one of the most recent forms of open innovation networks integrating multiple concepts such as the transition to low-carbon economies (Evans \& Karvonen, 2014). Consequently, marine RwLs provide a promising pathway towards solving potential multi-use conflicts and a sustainable blue economy.

\section{Limitations of marine RwLs}

Apart from the manifold opportunities and benefits that marine RwLs have to offer, the approach, just like every other method, has its limitations. RwLs are based on public participation but while there is wide agreement that participation is beneficial, there is little agreement on how exactly to do it and mixed experiences on the actual success of participation (Callahan, 2007). Reviews of available empirical evidence on participatory processes highlight that their benefits (e.g. trust building and reduction of social conflicts) are not necessarily realized (Flannery et al., 2018; Newig et al., 2013; Newig \& Fritsch, 2009; Reed, 2008). Since the 1960 's it has been repeatedly emphasized that many participatory processes fail because of mere tokenism, in which the have-nots are informed or heard but the power-holders retain the right to decide (Arnstein, 1969; Hoppe, 2011; White, 1996). Moreover, many of the societal challenges associated with the ocean are large-scale and global ocean solutions require international governance. However, RwLs are mainly used to address local issues and an upscaling to derive global solutions has limitations. That said, achieving sustainable transformations on a local level is of course a prerequisite for finding wide-ranging solutions and hence RwLs can be part of the basis to develop global transformative pathways.

\section{Summary}

In summary, RwLs are currently gaining traction as a method and approach for the co-creation of target and transformation knowledge. Here we have synthesised knowledge on the potentials of RwLs as a transdisciplinary approach to research, considering how they act as a way of exploring options for sustainable ocean futures through experimentation that may well work towards much-needed and just transformations over the coming years of the Ocean Decade and beyond. Developing them further nevertheless requires the respective design and budgeting in transdisciplinary research projects that aim at the co-creation of knowledge and possible pathways towards sustainable futures together with stakeholders from policy-making, the private sector and (non-)governmental organisations. The aim is to develop RwLs as transformative tools to build the required science-policy-practice networks for novel governance practices thereby contributing to the 2030 Agenda for Sustainable Development.

\section{Acknowledgements}

$\mathrm{AF}, \mathrm{UJ}, \mathrm{KP}$ and $\mathrm{HH}$ acknowledge support by the HIFMB, a collaboration between the Alfred-WegenerInstitute, Helmholtz-Center for Polar and Marine Research and the Carl-von-Ossietzky University Oldenburg, initially funded by the Ministry of Science and Culture of Lower Saxony (MWK) and the Volkswagen Foundation through the 'Niedersächsisches Vorab' grant program (ZN3285). UJ, KP and $\mathrm{HH}$ acknowledge support by the Federal Ministry of Education and Research (BMBF) through the project CREATE (03F091A), part of the research mission 'Protection and Sustainable use of Marine Areas' within the German Marine Research Alliance (DAM), as well as funding by the Belmont-Forum project MARISCO funded through BMBF (03F0836A). OZ acknowledges financial support for DFKI and 'Gute Küste Niedersachsen' by MWK through 'Niedersächsisches Vorab' (ZN3480, ZN3556, ZN3722). GK acknowledges support by the BMBF funding scheme 'Innovation and structural change - WIR!' for 
the RwL 'WissenSchafft Lebensraum (WSL)'. The authors thank Susanne Landis (@scienstration) for the scientific illustration.

\section{Conflict of interest}

The authors declare no conflict of interest.

\section{Authors' contributions}

The idea for this manuscript was originally developed by HH and AF; AF led the writing of the manuscript; $\mathrm{AF}, \mathrm{KP}$ and JH significantly contributed to drafting the outline. All authors contributed to writing and revising the manuscript and gave final approval for its publication.

\section{References}

Abelson, A., Halpern, B. S., Reed, D. C., Orth, R. J., Kendrick, G. A., Beck, M. W., Belmaker, J., Krause, G., Edgar, G. J., Airoldi, L., Brokovich, E., France, R., Shashar, N., de Blaeij, A., Stambler, N., Salameh, P., Shechter, M., \& Nelson, P. A. (2016). Upgrading marine ecosystem restoration using ecological-social concepts. BioScience, 66(2), 156-163. https://doi.org/10.1093/BIOSCI/BIV171

Abelson, A., Reed, D. C., Edgar, G. J., Smith, C. S., Kendrick, G. A., Orth, R. J., Airoldi, L., Silliman, B., Beck, M. W., Krause, G., Shashar, N., Stambler, N., \& Nelson, P. (2020). Challenges for restoration of coastal marine ecosystems in the Anthropocene. Frontiers in Marine Science, 7(544105), 1-14. https://doi.org/10.3389/FMARS.2020.544105

Abhold, K., Hoffmann, H., \& McGlade, K. (2019). Ocean as a global commons: International governance and the role of Germany. Report to the Science Platform Sustainability 2030. https://doi.org/10.2312/iass.2019.039

Acri, F., Bastianini, M., Bernardi Aubry, F., Camatti, E., Boldrin, A., Bergami, C., Cassin, D., de Lazzari, A., Finotto, S., Minelli, A., Oggioni, A., Pansera, M., Sarretta, A., Socal, G., \& Pugnetti, A. (2020). A long-term (1965-2015) ecological marine database from the LTER-Italy Northern Adriatic Sea site: Plankton and oceanographic observations. Earth System Science Data, 12(1), 215-230. https://doi.org/10.5194/ESSD-12-215-2020

Alger, J. (2021). Conserving the oceans: The politics of Large Marine Protected Areas. Oxford University Press. https://doi.org/10.1093/oso/9780197540534.001.0001

Anderson, C. R., \& McLachlan, S. M. (2016). Transformative research as knowledge mobilization: Transmedia, bridges, and layers. Action Research, 14(3), 295-317. https://doi.org/10.1177/1476750315616684

Anthony, K., Bay, L. K., Costanza, R., Firn, J., Gunn, J., Harrison, P., Heyward, A., Lundgren, P., Mead, D., Moore, T., Mumby, P. J., van Oppen, M. J. H., Robertson, J., Runge, M. C., Suggett, D. J., Schaffelke, B., Wachenfeld, D., \& Walshe, T. (2017). New interventions are needed to save coral reefs. Nature Ecology \& Evolution, 1(10), 1420-1422. https://doi.org/10.1038/s41559-0170313-5

Antich, A., Palacín, C., Cebrian, E., Golo, R., Wangensteen, O. S., \& Turon, X. (2021). Marine biomonitoring with eDNA: Can metabarcoding of water samples cut it as a tool for surveying 
benthic communities? Molecular Ecology, 30(13), 3175-3188.

https://doi.org/10.1111/MEC.15641

Armitage, D. R., Plummer, R., Berkes, F., Arthur, R. I., Charles, A. T., Davidson-Hunt, I. J., Diduck, A. P., Doubleday, N. C., Johnson, D. S., Marschke, M., McConney, P., Pinkerton, E. W., \& Wollenberg, E. K. (2009). Adaptive co-management for social-ecological complexity. Frontiers in Ecology and the Environment, 7(2), 95-102. https://doi.org/10.1890/070089

Arnstein, S. R. (1969). A ladder of citizen participation. Journal of the American Institute of Planners, 35(4), 216-224. https://doi.org/10.1080/01944366908977225

Belhabib, D. (2021). Ocean science and advocacy work better when decolonized. Nature Ecology \& Evolution , 5(6), 709-710. https://doi.org/10.1038/s41559-021-01477-1

Bennett, N. J., Cisneros-Montemayor, A. M., Blythe, J., Silver, J. J., Singh, G., Andrews, N., Calò, A., Christie, P., di Franco, A., Finkbeiner, E. M., Gelcich, S., Guidetti, P., Harper, S., Hotte, N., Kittinger, J. N., le Billon, P., Lister, J., López de la Lama, R., McKinley, E., ... Sumaila, U. R. (2019). Towards a sustainable and equitable blue economy. Nature Sustainability, 2(11), 991-993. https://doi.org/10.1038/s41893-019-0404-1

Birnbaum, S. (2016). Environmental co-governance, legitimacy, and the quest for compliance: When and why is stakeholder participation desirable? Journal of Environmental Policy \& Planning, 18(3), 306-323. https://doi.org/10.1080/1523908X.2015.1077440

Blythe, J. L., Armitage, D., Bennett, N. J., Silver, J. J., \& Song, A. M. (2021). The politics of ocean governance transformations. Frontiers in Marine Science, 8(634718), 1-12. https://doi.org/10.3389/FMARS.2021.634718

Blythe, J., Silver, J., Evans, L., Armitage, D., Bennett, N. J., Moore, M. L., Morrison, T. H., \& Brown, K. (2018). The dark side of transformation: Latent risks in contemporary sustainability discourse. Antipode, 50(5), 1206-1223. https://doi.org/10.1111/ANTI.12405

Borja, A., White, M. P., Berdalet, E., Bock, N., Eatock, C., Kristensen, P., Leonard, A., Lloret, J., Pahl, S., Parga, M., Prieto, J. V., Wuijts, S., \& Fleming, L. E. (2020). Moving toward an agenda on ocean health and human health in Europe. Frontiers in Marine Science, 7(37), 1-19. https://doi.org/10.3389/fmars.2020.00037

Brandt, P., Ernst, A., Gralla, F., Luederitz, C., Lang, D. J., Newig, J., Reinert, F., Abson, D. J., \& von Wehrden, H. (2013). A review of transdisciplinary research in sustainability science. Ecological Economics, 92, 1-15. https://doi.org/10.1016/J.ECOLECON.2013.04.008

Bromley, D. W. (1998). Searching for sustainability: The poverty of spontaneous order. Ecological Economics, 24(2-3), 231-240. https://doi.org/10.1016/S0921-8009(97)00145-6

Brown, M., \& Peters, K. (Eds. ). (2018). Living with the sea: Knowledge, awareness and action. Routledge.

Callahan, K. (2007). Citizen participation: Models and methods. International Journal of Public Administration , 30(11), 1179-1196. https://doi.org/10.1080/01900690701225366

Cash, D. W., Clark, W. C., Alcock, F., Dickson, N. M., Eckley, N., Guston, D. H., Jäger, J., \& Mitchell, R. B. (2003). Knowledge systems for sustainable development. PNAS, 100(14), 8086-8091. https://doi.org/10.1073/PNAS.1231332100 
Caswell, B. A., Klein, E. S., Alleway, H. K., Ball, J. E., Botero, J., Cardinale, M., Eero, M., Engelhard, G. H., Fortibuoni, T., Giraldo, A. J., Hentati-Sundberg, J., Jones, P., Kittinger, J. N., Krause, G., Lajus, D. L., Lajus, J., Lau, S. C. Y., Lescrauwaet, A. K., MacKenzie, B. R., ... Thurstan, R. H. (2020). Something old, something new: Historical perspectives provide lessons for blue growth agendas. Fish and Fisheries, 21(4), 774-796. https://doi.org/10.1111/FAF.12460

Challies, E., Newig, J., Kochskämper, E., \& Jager, N. W. (2017). Governance change and governance learning in Europe: Stakeholder participation in environmental policy implementation. Policy and Society , 36(2), 288-303. https://doi.org/10.1080/14494035.2017.1320854

Chander, G., Hewison, T. J., Fox, N., Wu, X., Xiong, X., \& Blackwell, W. J. (2013). Overview of intercalibration of satellite instruments. IEEE Transactions on Geoscience and Remote Sensing, 51(3), 1056-1080. https://doi.org/10.1109/TGRS.2012.2228654

Cormier-Salem, M. C., \& Panfili, J. (2016). Mangrove reforestation: greening or grabbing coastal zones and deltas? Case studies in Senegal. African Journal of Aquatic Science, 41(1), 89-98. https://doi.org/10.2989/16085914.2016.1146122

Cornwall, A., \& Jewkes, R. (1995). What is participatory research? Social Science \& Medicine, 41(12), 1667-1676. https://doi.org/10.1016/0277-9536(95)00127-S

De Santo, E. M. (2018). Implementation challenges of area-based management tools (ABMTs) for biodiversity beyond national jurisdiction (BBNJ). Marine Policy, 97, 34-43.

https://doi.org/10.1016/J.MARPOL.2018.08.034

Dharmawan, B., Böcher, M., \& Krott, M. (2017). Endangered mangroves in Segara Anakan, Indonesia: Effective and failed problem-solving policy advice. Environmental Management, 60(3), 409-421. https://doi.org/10.1007/S00267-017-0868-6

Duarte, C. M. (2014). Global change and the future ocean: a grand challenge for marine sciences. Frontiers in Marine Science, 1(63), 1-16. https://doi.org/10.3389/fmars.2014.00063

Edgar, G. J., Stuart-Smith, R. D., Willis, T. J., Kininmonth, S., Baker, S. C., Banks, S., Barrett, N. S., Becerro, M. A., Bernard, A. T. F., Berkhout, J., Buxton, C. D., Campbell, S. J., Cooper, A. T., Davey, M., Edgar, S. C., Försterra, G., Galván, D. E., Irigoyen, A. J., Kushner, D. J., ... Thomson, R. J. (2014). Global conservation outcomes depend on marine protected areas with five key features. Nature , 506(7487), 216-220. https://doi.org/10.1038/nature13022

Engel, E., Fischer, R., \& Galetovic, A. (2020). When and how to use Public-Private Partnerships in infrastructure: Lessons from the international experience. https://doi.org/10.3386/w26766

Erickson, V. et al. (2012). Genetic resource management and climate change: Genetic options for adapting national forests to climate change. Washington, DC: USDA Forest Service, Forest Management.

Ertör, I., \& Hadjimichael, M. (2020). Editorial: Blue degrowth and the politics of the sea: rethinking the blue economy. Sustainability Science, 15, 1-10. https://doi.org/10.1007/S11625-019-00772Y

Evans, J., \& Karvonen, A. (2014). 'Give me a laboratory and I will lower Your carbon footprint!' Urban laboratories and the governance of low-carbon futures. International Journal of Urban and Regional Research, 38(2), 413-430. https://doi.org/10.1111/1468-2427.12077 
FAO. (2018). The State of World Fisheries and Aquaculture 2018 - Meeting the sustainable development goals.

FAO. (2020). The State of World Fisheries and Aquaculture 2020. Sustainability in action.

Fauville, G., Strang, C., Cannady, M. A., \& Chen, Y. F. (2019). Development of the International Ocean Literacy Survey: measuring knowledge across the world. Environmental Education Research, 25(2), 238-263. https://doi.org/10.1080/13504622.2018.1440381

Flannery, W., Healy, N., \& Luna, M. (2018). Exclusion and non-participation in Marine Spatial Planning. Marine Policy, 88, 32-40. https://doi.org/10.1016/J.MARPOL.2017.11.001

Fleming, L. E., Maycock, B., White, M. P., \& Depledge, M. H. (2019). Fostering human health through ocean sustainability in the 21st century. People and Nature, 1(3), 276-283. https://doi.org/10.1002/pan3.10038

Folke, C., Hahn, T., Olsson, P., \& Norberg, J. (2005). Adaptive governance of social-ecological systems. Annual Review of Environment and Resources, 30, 441-473. https://doi.org/10.1146/ANNUREV.ENERGY.30.050504.144511

Franke, A., Blenckner, T., Duarte, C. M., Ott, K., Fleming, L. E., Antia, A., Reusch, T. B. H., Bertram, C., Hein, J., Kronfeld-Goharani, U., Dierking, J., Kuhn, A., Sato, C., van Doorn, E., Wall, M., Schartau, M., Karez, R., Crowder, L., Keller, D., ... Prigge, E. (2020). Operationalizing ocean health: Toward integrated research on ocean health and recovery to achieve ocean sustainability. One Earth, 2, 1-9. https://doi.org/10.1016/j.oneear.2020.05.013

Fuchs, N., \& Krause, G. (in prep.). Real-world laboratories as a method to address wicked problems: Insights from a concept study in Bremerhaven (Germany).

Funtowicz, S. O., \& Ravetz, J. R. (1993). Science for the post-normal age. Futures, 25(7), 739-755. https://doi.org/10.1016/0016-3287(93)90022-L

GBRMPA. (2021). https://www.gbrmpa.gov.au/our-work/our-programs-and-projects/crown-ofthorns-starfish-management/crown-of-thorns-starfish-control-program.

Germond, B. (2018). Clear skies or troubled waters: The future of European ocean governance. European View, 17(1), 89-96. https://doi.org/10.1177/1781685818761594

Giakoumi, S., McGowan, J., Mills, M., Beger, M., Bustamante, R. H., Charles, A., Christie, P., Fox, M., Garcia-Borboroglu, P., Gelcich, S., Guidetti, P., Mackelworth, P., Maina, J. M., McCook, L., Micheli, F., Morgan, L. E., Mumby, P. J., Reyes, L. M., White, A., ... Possingham, H. P. (2018). Revisiting "success" and "failure" of marine protected areas: A conservation scientist perspective. Frontiers in Marine Science, 5(223), 1-5. https://doi.org/10.3389/FMARS.2018.00223

Gibbons, M., Limoges, C., Nowotny, H., \& Schwartzman, S. (1994). The new production of knowledge. The dynamics of science and research in contemporary societies. Sage Publications.

Glaser, M., \& Glaeser, B. (2014). Towards a framework for cross-scale and multi-level analysis of coastal and marine social-ecological systems dynamics. Regional Environmental Change, 14(6), 2039-2052. https://doi.org/10.1007/s10113-014-0637-5 
Goodyear-Ka'opua, N. (2018). Indigenous oceanic futures: Challenging settler colonialisms and militarization. In Indigenous and Decolonizing Studies in Education. Routledge. https://doi.org/10.4324/9780429505010-6

Hau'ofa, E. (1995). Our Sea of Islands. In Asia/Pacific as Space of Cultural Production. Duke University Press. https://doi.org/10.1515/9780822396116-008

Hau'ofa, E. (2008). We are the ocean. University of Hawaii Press. https://doi.org/10.1515/9780824865542/HTML

Hinkel, J., Bisaro, A., \& Swart, R. (2016). Towards a diagnostic adaptation science. Regional Environmental Change, 16, 1-5. https://doi.org/10.1007/s10113-015-0850-x

Hoegh-Guldberg, O., \& Bruno, J. F. (2010). The impact of climate change on the world's marine ecosystems. Science, 328(5985), 1523-1528. https://doi.org/10.1126/science.1189930

Hofmeyr, I. (2020). Imperialism above and below the water line: Making space up (and down) in a colonial port city. Interventions, 22(8), 1032-1044. https://doi.org/10.1080/1369801X.2019.1659172

Hoppe, R. (2011). Institutional constraints and practical problems in deliberative and participatory policy making. Policy and Politics, 39(2), 163-186. https://doi.org/10.1332/030557310X519650

Hornidge, A. K., Herbeck, J., Siriwardane-de Zoysa, R., \& Flitner, M. (2020). Epistemic mobilities: Following sea-level change adaptation practices in Southeast Asian cities. American Behavioural Scientist, 64(10), 1497-1511. https://doi.org/10.1177/0002764220947764

Hornidge, A. K., UI Hassan, M., \& Mollinga, P. P. (2011). Transdisciplinary innovation research in Uzbekistan - one year of 'Follow-the-Innovation.' Development in Practice, 21(6), 834-847. https://doi.org/10.1080/09614524.2011.582085

Hossain, M., Leminen, S., \& Westerlund, M. (2019). A systematic review of living lab literature. Journal of Cleaner Production, 213, 976-988. https://doi.org/10.1016/J.JCLEPRO.2018.12.257

Huning, S., Räuchle, C., \& Fuchs, M. (2021). Designing real-world laboratories for sustainable urban transformation: addressing ambiguous roles and expectations in transdisciplinary teams. Sustainability Science, 16(5), 1595-1607. https://doi.org/10.1007/S11625-021-00985-0

IPBES. (2019). Global assessment report on biodiversity and ecosystem services of the Intergovernmental Science-Policy Platform on Biodiversity and Ecosystem Services.

IPCC. (2019). Summary for policymakers. In: IPCC Special report on the ocean and cryosphere in a changing climate (H. O. Pörtner, D. C. Roberts, V. Masson-Delmotte, P. Zhai, M. Tignor, E. Poloczanska, K. Mintenbeck, M. Nicolai, A. Okem, J. Petzold, B. Rama, \& N. Weyer, Eds.).

Jouffray, J.-B., Blasiak, R., Norström, A. v., Österblom, H., \& Nyström, M. (2020). The Blue Acceleration: The Trajectory of Human Expansion into the Ocean. One Earth, 2(1), 43-54. https://doi.org/10.1016/J.ONEEAR.2019.12.016

Kelly, R., Evans, K., Alexander, K., Bettiol, S., Corney, S., Cullen-Knox, C., Cvitanovic, C., de Salas, K., Emad, G. R., Fullbrook, L., Garcia, C., Ison, S., Ling, S., Macleod, C., Meyer, A., Murray, L., Murunga, M., Nash, K. L., Norris, K., ... Pecl, G. T. (2021). Connecting to the oceans: supporting ocean literacy and public engagement. Reviews in Fish Biology and Fisheries 2021, 1-21. https://doi.org/10.1007/S11160-020-09625-9 
Knapp, S., Schweiger, O., Kraberg, A., Asmus, H., Asmus, R., Brey, T., Frickenhaus, S., Gutt, J., Kühn, I., Liess, M., Musche, M., Pörtner, H. O., Seppelt, R., Klotz, S., \& Krause, G. (2017). Do drivers of biodiversity change differ in importance across marine and terrestrial systems - Or is it just different research communities' perspectives? Science of The Total Environment, 574, 191-203. https://doi.org/10.1016/J.SCITOTENV.2016.09.002

Kollmuss, A., \& Agyeman, J. (2002). Mind the Gap: Why do people act environmentally and what are the barriers to pro-environmental behavior? Environmental Education Research, 8(3), 239-260. https://doi.org/10.1080/13504620220145401

Krause, G., Wolf, C., Happe, A. K., Hauck, J., Buttigieg, P. L., Fuchs, N., Scheve, J., König, C., Wittmer, H., \& Raab, K. (2020). Lessons learnt from linking global recommendations with localized marine restoration schemes and policy options by using mixed methods. Frontiers in Marine Science, 7(532), 1-9. https://doi.org/10.3389/FMARS.2020.00532

Kullman, K. (2013). Geographies of experiment/experimental geographies: A rough guide. Geography Compass, 7(12), 879-894. https://doi.org/10.1111/GEC3.12087

Last, A. (2012). Experimental geographies. Geography Compass, 6(12), 706-724. https://doi.org/10.1111/GEC3.12011

Lewin, K. (1946). Action research and minority problems. Journal of Social Issues, 2(4), 34-46. https://doi.org/10.1111/j.1540-4560.1946.tb02295.x

Mauser, W., Klepper, G., Rice, M., Schmalzbauer, B. S., Hackmann, H., Leemans, R., \& Moore, H. (2013). Transdisciplinary global change research: The co-creation of knowledge for sustainability. Current Opinion in Environmental Sustainability, 5(3-4), 420-431. https://doi.org/10.1016/J.COSUST.2013.07.001

McKinley, E., \& Fletcher, S. (2012). Improving marine environmental health through marine citizenship: A call for debate. Marine Policy, 36(3), 839-843. https://doi.org/10.1016/J.MARPOL.2011.11.001

MELUR (Ministerium für Energiewende, Landwirtschaft, Umwelt und ländliche Räume des Landes Schleswig-Holstein (2015). Strategie für das Wattenmeer 2100.

Mendenhall, E., de Santo, E., Nyman, E., \& Tiller, R. (2019). A soft treaty, hard to reach: The second inter-governmental conference for biodiversity beyond national jurisdiction. Marine Policy, 108, 103664. https://doi.org/10.1016/J.MARPOL.2019.103664

Mielke, J., Vermaßen, H., \& Ellenbeck, S. (2017). Ideals, practices, and future prospects of stakeholder involvement in sustainability science. PNAS, 114(50), E10648-E10657. https://doi.org/10.1073/PNAS.1706085114

Moss, R. H., Meehl, G. A., Lemos, M. C., Smith, J. B., Arnold, J. R., Arnott, J. C., Behar, D., Brasseur, G. P., Broomell, S. B., Busalacchi, A. J., Dessai, S., Ebi, K. L., Edmonds, J. A., Furlow, J., Goddard, L., Hartmann, H. C., Hurrell, J. W., Katzenberger, J. W., Liverman, D. M., ... Wilbanks, T. J. (2013). Hell and high water: Practice-relevant adaptation science. Science, 342(6159), 696-698. https://doi.org/10.1126/SCIENCE.1239569

Muelbert, J. H., Nidzieko, N. J., Acosta, A. T. R., Beaulieu, S. E., Bernardino, A. F., Boikova, E., Bornman, T. G., Cataletto, B., Deneudt, K., Eliason, E., Kraberg, A., Nakaoka, M., Pugnetti, A., Ragueneau, O., Scharfe, M., Soltwedel, T., Sosik, H. M., Stanisci, A., Stefanova, K., ... Zingone, A. 
(2019). ILTER - the international long-term ecological research network as a platform for global coastal and ocean observation. Frontiers in Marine Science, 6(527), 1-14.

https://doi.org/10.3389/FMARS.2019.00527

Narayan, S., Beck, M. W., Reguero, B. G., Losada, I. J., van Wesenbeeck, B., Pontee, N., Sanchirico, J. N., Ingram, J. C., Lange, G.-M., \& Burks-Copes, K. A. (2016). The effectiveness, costs and coastal protection benefits of natural and nature-based defences. PLOS ONE, 11(5), e0154735. https://doi.org/10.1371/journal.pone.0154735

Newig, J., Adzersen, A., Challies, E., Fritsch, O., \& Jager, N. (2013). Comparative analysis of public environmental decision-making processes - A variable-based analytical scheme. SSRN Electronic Journal, 37/13, 1-65. https://doi.org/10.2139/SSRN.2245518

Newig, J., \& Fritsch, O. (2009). Environmental governance: Participatory, multi-level - and effective? Environmental Policy and Governance, 19(3), 197-214. https://doi.org/10.1002/EET.509

Norström, A. v., Cvitanovic, C., Löf, M. F., West, S., Wyborn, C., Balvanera, P., Bednarek, A. T., Bennett, E. M., Biggs, R., de Bremond, A., Campbell, B. M., Canadell, J. G., Carpenter, S. R., Folke, C., Fulton, E. A., Gaffney, O., Gelcich, S., Jouffray, J. B., Leach, M., ... Österblom, H. (2020). Principles for knowledge co-production in sustainability research. Nature Sustainability, 3(3), 182-190. https://doi.org/10.1038/s41893-019-0448-2

Orth, R. J., Lefcheck, J. S., McGlathery, K. S., Aoki, L., Luckenbach, M. W., Moore, K. A., Oreska, M. P. J., Snyder, R., Wilcox, D. J., \& Lusk, B. (2020). Restoration of seagrass habitat leads to rapid recovery of coastal ecosystem services. Science Advances, 6(41), eabc6434. https://doi.org/10.1126/sciadv.abc6434

Partelow, S., Hornidge, A. K., Senff, P., Stäbler, M., \& Schlüter, A. (2020). Tropical marine sciences: Knowledge production in a web of path dependencies. PLOS ONE, 15(2), 1-25. https://doi.org/10.1371/JOURNAL.PONE.0228613

Pendleton, L. H., Ahmadia, G. N., Browman, H. I., Thurstan, R. H., Kaplan, D. M., \& Bartolino, V. (2018). Debating the effectiveness of marine protected areas. ICES Journal of Marine Science, 75(3), 1156-1159. https://doi.org/10.1093/ICESJMS/FSX154

Peters, K. (2010). Future promises for contemporary social and cultural geographies of the sea. Geography Compass, 4(9), 1260-1272. https://doi.org/10.1111/J.1749-8198.2010.00372.X

Peters, K. (2020). The territories of governance: Unpacking the ontologies and geophilosophies of fixed to flexible ocean management, and beyond. Philosophical Transactions of the Royal Society B, 375(1814), 20190458. https://doi.org/10.1098/RSTB.2019.0458

Pogoda, B., Merk, V., Colsoul, B., Hausen, T., Peter, C., Pesch, R., Kramer, M., Jaklin, S., Holler, P., Bartholomä, A., Michaelis, R., \& Prinz, K. (2020). Site selection for biogenic reef restoration in offshore environments: The Natura 2000 area Borkum Reef Ground as a case study for native oyster restoration. Aquatic Conservation: Marine and Freshwater Ecosystems, 30(11), 21632179. https://doi.org/10.1002/aqc.3405

Pohl, C., \& Hirsch Hadorn, G. (2007). Principles for designing transdisciplinary research. Oekom Verlag. 
Quittkat, C., \& Kohler-Koch, B. (2013). Involving civil society in EU governance: The consultation regime of the European Commission. In: De-Mystification of Participatory Democracy: EUGovernance and Civil Society. Oxford University Press.

Reed, M. S. (2008). Stakeholder participation for environmental management: A literature review. Biological Conservation, 141(10), 2417-2431. https://doi.org/10.1016/J.BIOCON.2008.07.014

Reusch, T. B. H., Schubert, P. R., Marten, S. M., Gill, D., Karez, R., Busch, K., \& Hentschel, U. (2021). Lower Vibrio spp. abundances in Zostera marina leaf canopies suggest a novel ecosystem function for temperate seagrass beds. Marine Biology, 168(10), 1-6. https://doi.org/10.1007/S00227-021-03963-3/TABLES/2

Rochman, C. M. (2016). Strategies for reducing ocean plastic debris should be diverse and guided by science. Environmental Research Letters, 11(4), 041001. https://doi.org/10.1088/17489326/11/4/041001

Schäpke, N., Stelzer, F., Caniglia, G., Bergmann, M., Wanner, M., Singer-Brodowski, M., Loorbach, D., Olsson, P., Baedeker, C., \& Lang, D. J. (2018). Jointly experimenting for transformation? Shaping real-world laboratories by comparing them. GAIA - Ecological Perspectives for Science and Society, 27(1), 85-96. https://doi.org/10.14512/gaia.27.S1.16

Schlüter, A., Partelow, S., Torres Guevara, L. E., \& Jennerjahn, T. C. (2019). Coastal commons as social-ecological systems. In B. Hudson, J. Rosenbloom, \& D. Cole (Eds.), Routledge Handbook of the Study of the Commons. Routledge.

Schlüter, A., van Assche, K., Hornidge, A.-K., \& Văidianu, N. (2020). Land-sea interactions and coastal development: An evolutionary governance perspective. Marine Policy, 112, 103801. https://doi.org/10.1016/J.MARPOL.2019.103801

Schneidewind, U., Augenstein, K., Stelzer, F., \& Wanner; Matthias. (2018). Structure matters: Realworld laboratories as a new type of large-scale research infrastructure. A framework inspired by Giddens' structuration theory. GAIA , 27(S1), 12-17.

Schön, D. A. (1983). The reflective practitioner: How professionals think in action. Routledge.

Singleton, S. (2000). Co-operation or capture? The paradox of co-management and community participation in natural resource management and environmental policy-making. Environmental Politics , 9(2), 1-21. https://doi.org/10.1080/09644010008414522

Steinberg, P. E. (2001). The social construction of the ocean. Cambridge University Press.

Steinberg, P., \& Peters, K. (2015). Wet ontologies, fluid spaces: Giving depth to volume through oceanic thinking. Environment and Planning D: Society and Space, 33(2), 247-264. https://doi.org/10.1068/D14148P

Stoll-Kleemann, S. (2019). Feasible options for behavior change toward more effective ocean literacy: A systematic review. Frontiers in Marine Science, 6(273), 1-14. https://doi.org/10.3389/FMARS.2019.00273

Temmerman, S., \& Kirwan, M. L. (2015). Building land with a rising sea. Science, 349(6248), 588-589. American Association for the Advancement of Science. https://doi.org/10.1126/science.aac8312 
Temmerman, S., Meire, P., Bouma, T. J., Herman, P. M. J., Ysebaert, T., \& de Vriend, H. J. (2013). Ecosystem-based coastal defence in the face of global change. Nature, 504(7478), 79-83. https://doi.org/10.1038/nature12859

Tilot, V., Willaert, K., Guilloux, B., Chen, W., Mulalap, C. Y., Gaulme, F., Bambridge, T., Peters, K., \& Dahl, A. (2021). Traditional dimensions of seabed resource management in the context of deep sea mining in the Pacific: Learning from the socio-ecological interconnectivity between island communities and the ocean realm. Frontiers in Marine Science, 8(637938), 1-27. https://doi.org/10.3389/FMARS.2021.637938

Tolochko, P., \& Vadrot, A. B. M. (2021). The usual suspects? Distribution of collaboration capital in marine biodiversity research. Marine Policy, 124(104318), 1-15. https://doi.org/10.1016/J.MARPOL.2020.104318

UI Hassan, M., Hornidge, A.-K., Akramkhanov, A., Rudenko, I., Djanibekov, N., \& van Veldhuizen, L. (2011). Follow the innovation-participatory testing and adaptation of agricultural innovations in Uzbekistan: guidelines for researchers and practitioners. Universität Bonn, Zentrum Für Entwicklungsforschung.

Ullmann, J., \& Stachowitsch, M. (2015). A critical review of the Mediterranean sea turtle rescue network: a web looking for a weaver. Nature Conservation, 10, 45-69. https://doi.org/10.3897/natureconservation.10.4890

Underhill-Sem, Y. T. R. R. o. T. (2020). The audacity of the ocean: Gendered politics of positionality in the Pacific. Singapore Journal of Tropical Geography, 41(3), 314-328. https://doi.org/10.1111/SJTG.12334

UNESCO. (2020). The science we need for the ocean we want. The United Nations Decade of Ocean Science for Sustainable Devlopment (2021-2030) (pp. 1-19).

van Assche, K., Hornidge, A.-K., Schlüter, A., \& Vaidianu, N. (2020). Governance and the coastal condition: Towards new modes of observation, adaptation and integration. Marine Policy, 112(103413), 1-10. https://doi.org/10.1016/J.MARPOL.2019.01.002

van Oppen, M. J. H., Oliver, J. K., Putnam, H. M., \& Gates, R. D. (2015). Building coral reef resilience through assisted evolution. PNAS, 112(8), 2307-2313. https://doi.org/10.1073/pnas.1422301112

van Slobbe, E., de Vriend, H. J., Aarninkhof, S., Lulofs, K., de Vries, M., \& Dircke, P. (2013). Building with Nature: In search of resilient storm surge protection strategies. Natural Hazards, 65(1), 947-966. https://doi.org/10.1007/s11069-012-0342-y

Visbeck, M., Kronfeld-Goharani, U., Neumann, B., Rickels, W., Schmidt, J., van Doorn, E., Matz-Lück, N., Ott, K., \& Quaas, M. F. (2014). Securing blue wealth: The need for a special sustainable development goal for the ocean and coasts. Marine Policy, 48, 184-191. https://doi.org/10.1016/J.MARPOL.2014.03.005

Wanner, M., Hilger, A., Westerkowski, J., Rose, M., Stelzer, F., \& Schäpke, N. (2018). Towards a cyclical concept of real-world laboratories. A transdisciplinary research practice for sustainability transitions. DisP - The Planning Review, 54(2), 94-114. https://doi.org/10.1080/02513625.2018.1487651 
Watson, V. (2014). Co-production and collaboration in planning - The difference. Planning Theory \& Practice , 15(1), 62-76. https://doi.org/10.1080/14649357.2013.866266

WBGU. (2016). Humanity on the move: Unlocking the transformative power of cities.

Weller, R. A., Baker, D. J., Glackin, M. M., Roberts, S. J., Schmitt, R. W., Twigg, E. S., \& Vimont, D. J. (2019). The challenge of sustaining ocean observations. Frontiers in Marine Science, 6(105), 118. https://doi.org/10.3389/FMARS.2019.00105

White, S. C. (1996). Depoliticising development: The uses and abuses of participation. Development in Practice , 6(1), 6-15. https://doi.org/10.1080/0961452961000157564

Yusoff, K. (2018). A billion black Anthropocenes or none. University of Minnesota Press.

Zijlstra, J. (2019). Research programme. Living Lab Holwerd aan Zee, testing ground for the development of the Wadden Sea coastal area. Accessed 12/03/2021 https://www.holwerdaanzee.nl/living-lab/.

Zivkovic, S. (2018). Systemic innovation labs: a lab for wicked problems. Social Enterprise Journal, 14(3), 348-366. https://doi.org/10.1108/SEJ-04-2018-0036

Zondi, S. (2020). The post-colonial is neocolonial in the Indian Ocean region: The case of Chagos seen through the African-centred decolonial theoretical lens. Africa Review , 12(2), 119-132. 